\title{
ANALIZA DELOVANJA ZVEZE LASTNIKOV GOZDOV SLOVENIJE S CILJEM NJENEGA IZBOLJŠANJA - ALI OBSTAJAJO MOŽNOSTI ZA VZPOSTAVITEV NOVIH POSLOVNIH MODELOV SODELOVANJA S ČLANI? ANALYZING THE OPERATION OF THE SLOVENIAN FOREST OWNERS ASSOCIATION WITH THE AIM OF IMPROVING IT - ARE THERE OPPORTUNITIES FOR ESTABLISHING NEW BUSINESS MODELS OF COOPERATION WITH ITS MEMBERS?
}

\author{
Kaja PLEVNIK ${ }^{1}$, Špela PEZDEVŠEK MALOVRH² \\ (1) Gozdarski inštitut Slovenije, kaja.plevnik@gozdis.si \\ (2) Univerza v Ljubljani, Biotehniška fakulteta, Oddelek za gozdarstvo in obnovljive gozdne vire, spela.pezdevsek.malovrh@bf.uni-lj.si
}

\begin{abstract}
IZVLEČEK
Zveza lastnikov gozdov Slovenije (ZLGS), ki povezuje lokalna združenja zasebnih lastnikov gozdov na državnem nivoju, se srečuje s problemom profesionalizacije pri svojem delovanju, zato je njeno delovanje omejeno. V cilju izboljšanja delovanja ZLGS in možnega poslovnega sodelovanja s člani v okviru novih poslovnih modelov smo opravili vodene intervjuje s predstavniki članov ZLGS ( $\mathrm{n}$ = 24). Člani ZLGS so zadovoljni z delom ZLGS, predvsem zaradi njene vključenosti v procese sprejemanja zakonodaje. V prihodnje bi si člani želeli predvsem, da bi ZLGS delovala na področju skupne prodaje gozdno lesnih sortimentov (GLS), zato so izkazali velik interes za poslovno sodelovanje z ZLGS v smeri koordinirane prodaje GLS. Za uresničitev tega novega poslovnega modela je treba v prvi vrsti poskrbeti za promocijo koordinirane prodaje na lokalnem nivoju, zagotoviti primeren kader v ZLGS in vzpostaviti vezi med ponudniki in odkupovalci GLS.
\end{abstract}

Ključne besede: zasebni gozdovi, gospodarjenje, povezovanje zasebnih lastnikov gozdov, Zveza lastnikov gozdov Slovenije, poslovni modeli

\begin{abstract}
The Slovenian Forest Owners Association (FOAS), which connects local associations of private forest owners at the national level, is facing the problem of professionalizing its activities. Thus, its activities are limited. In order to improve the operation of the FOAS and possible business cooperation with its members within the framework of new business models, we conducted interviews with representatives of FOAS members $(n=24)$. FOAS members are satisfied with the work of the FOAS, mainly due to its involvement in the legislative process. FOAS members expect that the FOAS will become active in the area of joint timber sales in the future, which is why they showed great interest in business cooperation with the FOAS towards coordinated timber sales. In order to implement this new business model, it is first necessary to promote coordinated sales among forest owners, provide suitable personnel and establish links between timber suppliers and buyers.
\end{abstract}

Key words: private forests, management, private forest owner cooperation, Forest Owners Association of Slovenia, business models

\section{UVOD}

\section{INTRODUCTION}

Zasebni lastniki gozdov imajo v lasti velik delež evropskih gozdov (okoli 60 \% vseh gozdov je v zasebni lasti), ki pomembno prispevajo k trajnostnemu razvoju ekosistemov ter oskrbi trga z gozdno-lesnimi sortimenti (GLS) (Fabra-Crespo in Rojas-Briales, 2015; Matilainen in sod., 2019). Slovenija se z 58,1-odstotno gozdnatostjo uvršča med najbolj gozdnate države v Evropi, kar 79,2 \% vseh gozdov pa je v zasebni lasti (podatek za 1. 2018; Poročilo ..., 2019). Za te gozdove je značilno, da so $\mathrm{v}$ lasti velikega števila lastnikov (okoli 314.000) in solastnikov (okoli 489.000) ter da so razdrobljeni na posamezne prostorsko ločene parcele (Medved in sod., 2010). Povprečna zasebna gozdna posest je zelo majhna, v povprečju meri le okoli 2,6 ha (Poročilo ..., 2019). Zaradi ekonomskih (npr. doseganje nizkih cen pri prodaji GLS in posledične neodvisnosti zasebnih lastnikov gozdov od prihodkov iz gozda) in socialnih razlogov (npr. pomanjkanje znanja 
o gospodarjenju z gozdovi, starostne strukture zasebnih lastnikov gozda) se pojavlja pri zasebnih lastnikih gozdov nezainteresiranost za gospodarjenje z gozdovi (Pezdevšek Malovrh, 2010; Kumer, 2017). Vse našteto je pripeljalo do nepopolne izkoriščenosti potenciala (ekološkega, socialnega in ekonomskega), ki ga imajo zasebni gozdovi, poleg tega pa se zasebni lastniki gozdov srečujejo tudi s problemom neupoštevanosti, prezrtosti in slabe zastopanosti v političnih procesih (Aurenhammer in sod., 2017).

$\mathrm{Z}$ namenom učinkovitejšega gospodarjenja $\mathrm{z}$ zasebnimi gozdovi, izmenjave informacij in znanja, predvsem pa boljšega zastopanja interesov zasebnih lastnikov gozda, se le-ti povsod po Evropi, tudi v Sloveniji, povezujejo $\mathrm{v}$ različne organizacijske oblike (Glück in sod., 2010; Weiss in sod., 2012; Hrib in sod., 2017; Pezdevšek Malovrh in sod., 2017; Stoettner in Ni Dhubhain, 2019; Černač in Pezdevšek Malovrh, 2020). Organizacijske oblike zasebne lastnike gozdov izobražujejo in jim dajejo informacije, povezane z gospodarjenjem, zastopajo njihove interese $\mathrm{v}$ procesih oblikovanja in sprejemanja zakonodaje, povezane $\mathrm{z}$ gozdom, ter jim zagotavljajo podporo pri prodaji GLS in izvedbi del v gozdovih (Kittredge, 2005; Pezdevšek Malovrh in sod., 2011). Pri svojem delu pa se organizacijske oblike povezovanja srečujemo s številnimi problemi, med katerimi je glavni zagotovo nizka stopnja aktivnosti zasebnih lastnikov gozdov v teh oblikah (Weiss in sod., 2012; Leban, 2014; Põllumäe in sod., 2016). Nadalje so problemi oblik povezovanja zasebnih lastnikov gozdov povezani še $\mathrm{z}$ njihovo močjo v političnih procesih (Šalka in sod., 2016; Dobšinska in sod., 2020) oziroma učinkovitostjo delovanja tako na poslovnem kot tudi na političnem področju (Leban, 2014; Aurenhammer in sod., 2017).

Izboljšati organiziranost zasebnih lastnikov gozdov s spodbujanjem povezovanja je tudi eden izmed ciljev Resolucije o nacionalnem gozdnem programu (Resolucija o Nacionalnem gozdnem programu, 2007). K združevanju v društva lastnikov gozdov (DLG) in strojne krožke (SK) se zasebne lastnike gozdov med drugim spodbuja tudi v Zakonu o gozdovih (Zakon o spremembah in dopolnitvah Zakona o gozdovih, 2007). Zaradi omenjenih problemov, povezanih s posestno in lastniško strukturo zasebnih gozdov, ter prepoznane potrebe s strani gozdarske zakonodaje se zasebni lastniki gozdov v Sloveniji v zadnjem obdobju najpogosteje povezujejo v DLG (Plevnik, 2020). Le ta so aktivna na različnih področjih, največ pozornosti pa posvečajo izobraževanju, informiranju članov in organiziranju ekskurzij ter dogodkov (Pezdevšek Malovrh, 2010; Le- ban, 2014; Breznikar in sod., 2017). Na nacionalnem nivoju se posamezne oblike povezovanja zasebnih lastnikov gozdov združujejo v Zvezo lastnikov gozdov Slovenije (ZLGS), ki je krovna organizacija zasebnih lastnikov gozdov v Sloveniji (Statut Zveze lastnikov gozdov Slovenije, 2015). ZLGS se od ustanovitve dalje srečuje s problemom nestalnosti financiranja ter problemom profesionalizacije dela, saj nima redno zaposlenega kadra. Posledično je njeno delovanje omejeno zgolj na posamezne naloge iz Statuta ZLGS, med katerimi je najpomembnejša zastopanje interesov zasebnih lastnikov gozdov pri sprejemanju z gozdom povezane zakonodaje (Plevnik, 2020). Zato ne preseneča, da si ZLGS želeli v prihodnje po vzoru dobrih praks iz tujine razširiti svoje delovanje tudi na področja poslovne narave, kot je na primer skupna ali koordinirana prodaja GLS, s čimer bi premostila predvsem finančne in posledično kadrovske težave, s katerimi se srečuje.

V cilju izboljšanja delovanja ZLGS ter zagotavljanja gospodarskih koristi za njene člane smo v raziskavi analizirali pripravljenost članov za poslovno sodelovanje z ZLGS, s ciljem vzpostavitve novih poslovnih modelov. Na podlagi ugotovitev smo podali smernice za prihodnje, bolj usmerjeno delovanje ZLGS oziroma za razvoj novih poslovnih modelov sodelovanja s člani.

\section{OBJEKT RAZISKAVE}

\section{RESEARCH OBJECT}

Objekt raziskave je ZLGS, ki je prostovoljna organizacija, ustanovljena leta 2006 v skladu z Zakonom o društvih (Zakon o društvih, 2006). Njeni člani so po statutu ZLGS lahko lokalna, interesna in druga društva oziroma klubi, ki so jih ustanovili zasebni lastniki gozdov z namenom povezovanja na področju gozdarstva in imajo lastnost pravne osebe s pravicami in obveznostmi, določenimi z Ustavo Republike Slovenije (Ustava Republike Slovenije, 1991), Zakonom o društvih (Zakon o društvih, 2006) ter Statutom ZLGS (Statut Zveze lastnikov gozdov Slovenije, 2015) in internimi pravili posameznih oblik povezovanja. $V$ večini so člani ZLGS DLG. Teh je od 29 članov kar 24. Ostali člani ZLGS so tudi gozdarsko društvo Lisjak, trije SK, in sicer SK Bled, SK Gorjan in SK Kmetovalec Grosuplje ter Solastniška skupnost »Planinca« Begunje na Gorenjskem. V vse oblike povezovanja, ki so člani ZLGS, je vključenih 3025 članov. V povprečju imajo oblike povezovanja zasebnih lastnikov gozdov, ki so člani ZLGS, 126 članov, od katerih jih je bilo v letu 2019 v povprečju aktivnih 30 \% (Plevnik, 2020).

ZLGS je bila ustanovljena $\mathrm{z}$ namenom, da zastopa in usklajuje interese svojih članov, pospešuje razvoj 
zasebnega sektorja gozdarstva kot sestavnega dela razvoja podeželja, veča pozitivne učinke sonaravnega in trajnostnega gospodarjenja z gozdovi v zasebni lasti, utrjuje in veča gospodarsko moč gozdnih posestnikov ob upoštevanju načel trajnosti, sonaravnosti in večnamenskosti slovenskih gozdov, pospešuje izobraževanja s področja gozdarstva ter ozavešča zasebne lastnike gozdov in širšo javnost o pomenu gozda in gozdarstva, pospešuje skrb za varstvo narave in zdravega človekovega okolja in skrbi za založništvo in izdajanje informativne, strokovne, vzgojne in druge gozdarske literature.

V statutu si je ZLGS zadala številne naloge, ki so povezane z zastopanjem interesov članov pri sprejemanju zakonodaje, povezane z gozdovi in njihovim gospodarjenjem; s tekočim obveščanjem članov o aktualnih razmerah in novostih v gozdarstvu; s pomočjo in svetovanjem članom pri trženju GLS in primarni predelavi GLS; z izvajanjem ukrepov za nadaljnje izobraževanje članov za gospodarjenje z gozdom; s spodbujanjem in podporo gozdnim posestnikom pri usposabljanju za storitve z gozdarsko mehanizacijo z namenom, da bi $\mathrm{v}$ gozdovih drugih lastnikov opravljali dela čim bolje usposobljeni delavci in s popularizacijo rabe lesa kot okolju prijazne surovine (Statut Zveze lastnikov gozdov Slovenije, 2015).

Na podlagi raziskave Plevnik (2020) vidimo, da se je ZLGS v vseh letih delovanja največ posvečala predvsem zastopanju interesov zasebnih lastnikov gozdov pri oblikovanju in sprejemanju zakonodaje, povezane z gozdom, pri čemer je dajala pripombe na osnutke zakonov (npr. Zakon o gozdovih, Zakon o lovu, Zakon o ohranjanju narave), pravilnike in uredbe, razpise iz Programa razvoja podeželja in certifikacijske sheme. Sodelovala je v različnih delovnih skupinah, povezanih z gozdarstvom pri Ministrstvu za kmetijstvo, gozdarstvo in prehrano in v Državnem zboru, sodelovala pa je tudi z vladnimi, nevladnimi organizacijami in izobraževalnimi ustanovami. Vseskozi je sodelovala pri organizaciji licitacije vrednejših GLS v Slovenj Gradcu. Od ustanovitve dalje se je ZLGS veliko posvečala tekočemu obveščanju članov o aktualnih razmerah in novostih v gozdarstvu prek spletne strani, glasil, mesečnih e-novic in socialnih omrežij.

Glavni vir financiranja ZLGS so trenutno nepovratna sredstva za 3. ukrep Pomoč delovanju nepridobitnih združenj na področju kmetijstva, gozdarstva in podeželja pri Agenciji Republike Slovenije za kmetijske trge in razvoj podeželja, Ministrstva za kmetijstvo, gozdarstvo in prehrano. Vir financiranja so tudi članarine članov in v manjši meri donatorska sredstva (Hren, 2019).

\section{MATERIALI IN METODE}

\section{MATERIALS AND METHODS}

Za pridobitev informacij o videnju delovanja ZLGS s strani njenih članov, možnostih za začetek poslovnega sodelovanja med ZLGS in njenimi člani ter vzpostavitve novih poslovnih modelov smo opravili poglobljene osebne intervjuje s predsedniki/predstavniki oblik povezovanja zasebnih lastnikov gozdov, ki so člani ZLGS. V ZLGS je bilo do 1. 10. 2019 včlanjenih 29 oblik povezovanja lastnikov gozdov na lokalnem nivoju. Pri dogovarjanju za izvedbo intervjujev smo izvedeli, da je 5 DLG (DLG Luče, DLG Gornji Grad, DLG pod Gorjanci, DLG Kupljenik in DLG Keltika) prekinilo z delovanjem ali pa so v procesu prekinitve. Te smo iz naše raziskave izključili in tako intervjuvali 24 aktivnih članov ZLGS oktobra in novembra leta 2019. Intervju je v povprečju trajal 28 minut.

Za potrebe raziskave, ki je potekala v okviru magistrske naloge (Plevnik, 2020), smo intervju pripravili skupaj s strokovnim tajnikom ZLGS, ki nam je svetoval o tem, katera vprašanja vključiti v intervju, da bodo rezultati imeli dejansko uporabno vrednost za ZLGS oziroma bodo omogočili ZLGS tudi poslovno sodelovanje s svojimi člani. Intervju je bil sestavljen iz treh tematskih sklopov, in sicer so nas v prvem sklopu zanimale splošne informacije o članih ZLGS in njihovih interesih, v drugem sklopu nas je zanimala ocena dela ZLGS in pričakovanja članov od ZLGS v prihodnosti, v tretjem sklopu pa možnost za poslovno sodelovanje med člani in ZLGS v okviru novih poslovnih modelov. Intervju je obsegal 25 vprašanj pretežno odprtega tipa.

Kratek intervju o delovanju ZLGS smo opravili tudi $s$ trenutnim predsednikom ZLGS, s ciljem da pridobimo informacije o trenutnem delovanju ZLGS ter se seznanimo z vizijo ter cilji za prihodnost.

Za zagotavljanje anonimnosti smo v rezultatih za intervjuvance uporabljali generične kode v obliki [ORG $X Y]$. Te so generirane naključno in niso povezane s katerim koli vrstnim redom, ki je bil uporabljen $\mathrm{v}$ raziskavi.

Intervjuje smo analizirali s pomočjo kvalitativne analize teksta v programu MAXQDA 2020, ki je orodje za analizo vsebine (»Content analysis«). Analiza vsebine je raziskovalna metoda, ki se uporablja za identificiranje sporočil in vzorcev v pridobljenem besedilu, $\mathrm{v}$ našem primeru intervjujev (Neuendorf, 2002). Analiza vsebine je lahko tako kvalitativna (osredotočena na interpretiranje in razumevanje) kot kvantitativna (osredotočena na štetje in merjenje). V obeh primerih je treba najprej kategorizirati oziroma kodirati besede, teme in koncepte in potem analizirati vsebino (Krippendorff, 2004). 


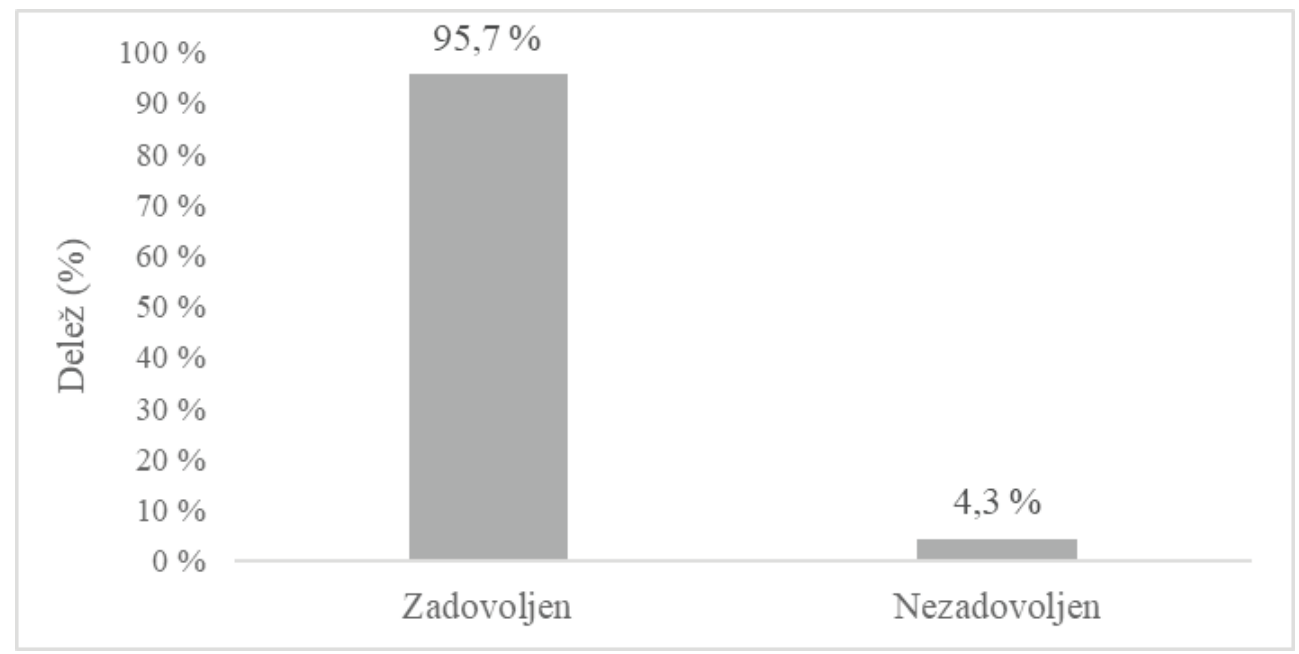

Slika 1: Splošno zadovoljstvo članov z delom ZLGS

Fig. 1: General satisfaction of members with the work of the FOAS

Glede na omenjeni metodološki pristop smo intervjuje analizirali v treh korakih. V prvem smo pripravili kodirno knjigo, ki nam je bila v pomoč v procesu kodiranja besedila. $\mathrm{V}$ tej fazi posameznim delom besedila pripisujemo pojme iz kodirne knjige in tako organiziramo podatke. Ko je kodiranje končano, je treba zbrane podatke preučiti in ugotoviti, ali obstajajo vzorci pojavljanja določene vsebine (npr. pogostost pojavljanja določene kode oziroma teme) ter priti do zaključkov, pri čemer pa uporabljamo tako kvalitativni kot kvantitativni pristop. (Krippendorff, 2004). Kodirane rezultate intervjujev smo analizirali s pomočjo statističnih metod, in sicer deskriptivne statistike - frekvenčne porazdelitve (Field, 2018), pri čemer smo uporabili Microsoft Excel 2016. Tako smo pri analizi vsebine kvalitativni metodi dodali še kvantitativno metodo.

\section{REZULTATI IN RAZPRAVA}

\section{RESULTS AND DISCUSSION}

Z intervjuji smo želeli pridobiti informacije o: a) oceni dela ZLGS in pričakovanjih članov od ZLGS v prihodnosti; b) trenutnem stanju poslovnega sodelovanja $\overline{\text { na lokalnem nivoju, ter c) možnostih za poslovno sode- }}$ lovanje ZLGS z njenimi člani v okviru novih poslovnih modelov (skupna ali koordinirana prodaja GLS).

\subsection{Pogled članov na delovanje ZLGS}

4.1 Members' view of the operation of the FOAS

4.1.1 Splošno zadovoljstvo članov z delom ZLGS

4.1.1 General satisfaction of members with the work of the FOAS

Po Statutu je glavni namen ZLGS, da zastopa in usklajuje interese svojih članov (Statut Zveze lastnikov gozdov Slovenije, 2015), zato nas je zanimalo, kakšno je splošno zadovoljstvo članov z delom ZLGS oziroma kaj je pripomoglo k temu (sliki 1 in 2).

Velika večina članov $(95,7$ \%) je z delom ZLGS zadovoljna (slika 1), predvsem zaradi njene vključenosti $\mathrm{v}$ politične procese in zastopanja lastnikovih interesov pri oblikovanju in sprejemanju zakonodaje $(47,6 \%)$ (slika 2). To lahko potrdimo z izjavama intervjuvancev: »Imamo nekoga, ki spremlja zadeve v politiki, da se oglasi, ko je pritisk na lastnino in da smo organizirani, da lahko stopimo skupaj in izražamo svoja stališča.«

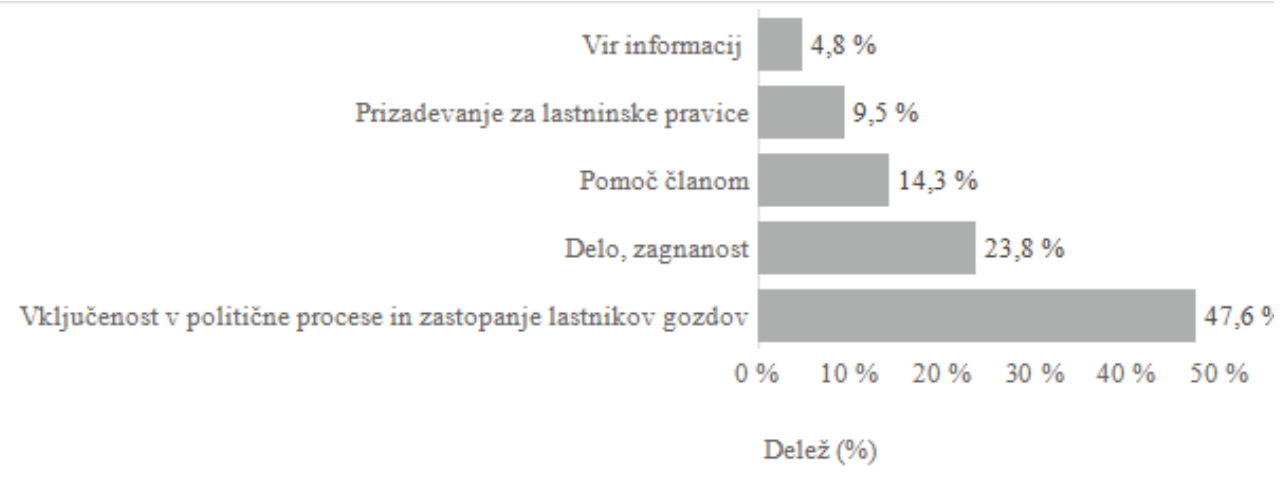

Slika 2: Razlogi za zadovoljstvo članov z delom ZLGS

Fig. 2: Reasons for members' satisfaction with the work of the FOAS 
[ORG 15] in »Dobro je že to, da sploh obstaja, saj je vsaj en subjekt, ki lahko v imenu vseh nas zasebnih lastnikov gozda nekaj vpraša ali zahteva na ministrstvu. « [ORG 11].

Kot pomemben razlog za zadovoljstvo $\mathrm{z}$ delom ZLGS so člani postavili v ospredje tudi delo in zagnanost kadra na ZLGS $(23,8 \%)$, kar potrdi tudi izjava intervjuvanca: »ZLGS se zelo trudi in je dejavna.« [ORG 7]. Tudi pomoč članom (14,3 \%) je za člane ZLGS pomemben razlog za njihovo zadovoljstvo. Intervjuvanca sta povedala: »Kar rabimo, tudi dobimo, v ZLGS nam pomagajo. " [ORG 2] in »ZLGS ima sedaj tajništvo, ki je vedno na voljo, da pomaga.« [ORG 24].

Kot eden izmed glavnih razlogov za nezadovoljstvo z delom ZLGS so člani navedli, da se ZLGS preveč posveča le vključenosti v politične procese in spremljanju zakonodaje, premalo pa dela v poslovni smeri (33 \%). To potrjuje tudi izjava intervjuvanca: »Zveza se trudi zgolj v bolj političnih okvirih, pri zakonodaji, pozablja pa na gospodarsko plat delovanja, ki bi ji lahko prinesla večjo neodvisnost." [ORG 11]. Enako pomemben razlog za nezadovoljstvo članov je tudi, da se malo zastavljenih nalog uresniči (33\%). Na to nakazuje izjava intervjuvanca: »Pričakujemo hitreje neke rezultate. Premalo zastavljenih stvari se uresniči.« [ORG 16].

Iz rezultatov je razvidno, da so člani ZLGS v splošnem zadovoljni z delom ZLGS, vendar pri njenem delu opažajo pomanjkljivosti, ki so povezane z neizpolnjevanjem vseh zastavljenih nalog v Statutu. Hkrati predlagajo možnosti za izboljšave, predvsem v smeri poslovnega delovanja ZLGS. Prav tako člani prepoznavajo, da so v upravnem odboru in v tajništvu ZLGS ljudje, ki si želijo sprememb v delovanju ZLGS. Ob trenutno omejenih finančnih sredstvih in posledično neprofesi- onalnem delovanju je sicer nemogoče pričakovati, da bi ZLGS uspelo uresničiti vse zastavljene naloge, je pa za prihodnje delovanje pomembno, da si ZLGS sama zagotovi finančno neodvisnost, kar bi lahko imelo za posledico profesionalizacijo njenega delovanja.

\subsubsection{Pogled članov na prihodnje delovanja ZLGS}

4.1.2 Members' view of future activities of the FOAS

ZLGS bi v primeru profesionalizacije začela delovati tudi na drugih področjih, ki jih ima zapisane med nalogami v Statutu oziroma bi razširila svoje delovanje v smeri poslovnega sodelovanja s člani v okviru novih poslovnih modelov (Hren, 2019). Intervjuvance smo prosili, naj navedejo področja delovanja, ki bi jim morala ZLGS v prihodnosti nameniti več pozornosti (slika 3).

Člani ZLGS menijo, da je eno glavnih področij povezano s skupno prodajo GLS (14,3 \%) (slika 3), kar potrjuje tudi izjava intervjuvanca: »ZLGS bi lahko začela delati na skupni prodaji, lahko bi nabrala velike količine $G L S$, večje kot DLG, in bi tako dosegali boljše rezultate na trgu GLS.« [ORG 21]. Hkrati pa so kot glavna področja navedli tudi svetovanje in pomoč pri gozdarskih razpisih ter organizacijo strokovnih ekskurzij (obe s 14,3 \%). Intervjuvanca sta povedala: „Lastniki bi rabili pomoč pri razpisih, da bi vedeli datume objave razpisov in pomoč pri izpolnjevanju vlog... [ORG 17] oziroma: »... dobro bi bilo, če bi se ZLGS lotila organiziranja izletov, ekskurzij..." [ORG 1].

Med pomembna področja sodi tudi spodbujanje malih gozdnih posestnikov za aktivnejše gospodarjenje z gozdom (12,7 \%), na kar kaže izjava intervjuvanca: »Vzpodbuditi bi morali tiste male zasebne lastnike gozdov, ki ne gospodarijo z gozdom, da se aktivirajo."

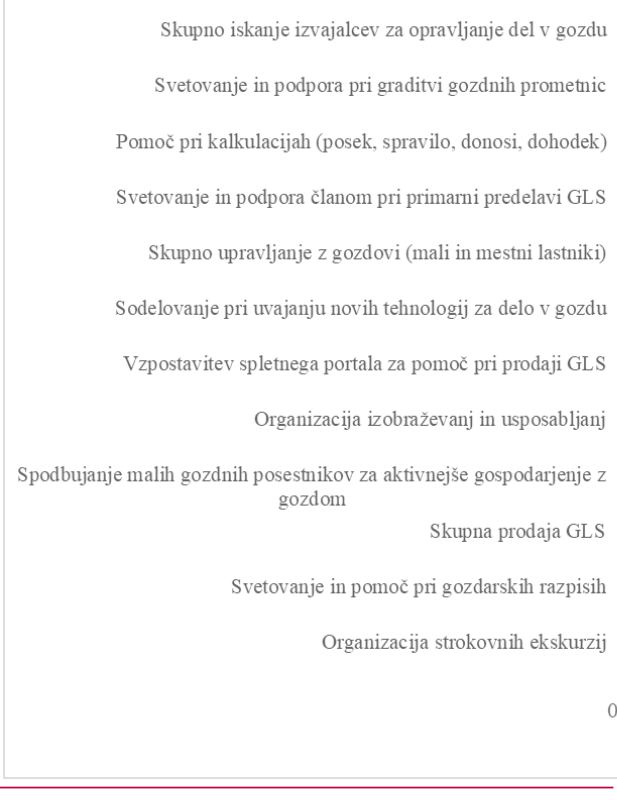

Slika 3: Področja prihodnjega delovanja ZLGS

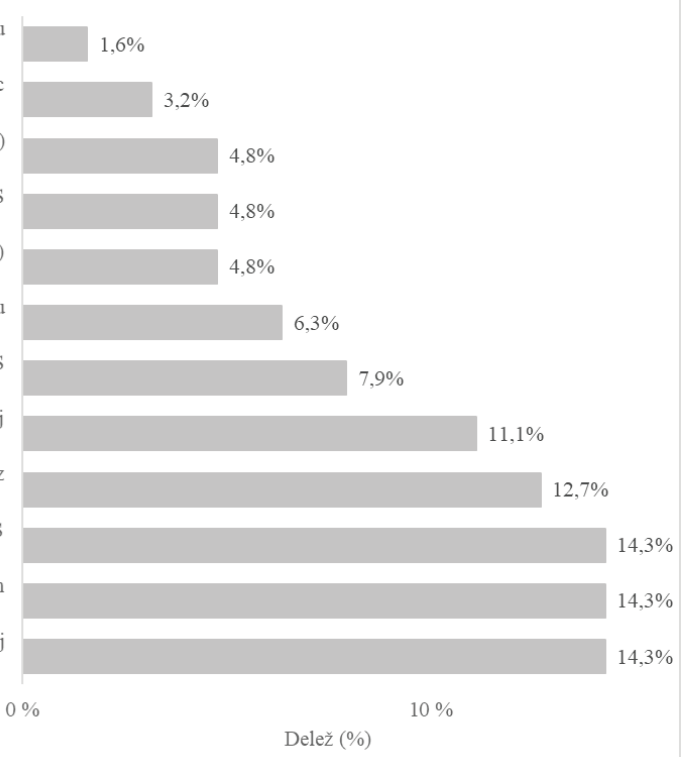

Fig. 3: Areas of future activities of the FOAS 
[ORG 2], ter organizacija izobraževanj in usposabljanj (11,1 \%): »... tudi tečaji ali izobraževanja o specifičnih gozdarskih temah bi prišli zelo prav..." [ORG 16]. Sledijo še področja, ki so povezana z organizacijo izobraževanj in usposabljanj, vzpostavitvijo spletnega portala za pomoč pri prodaji GLS, sodelovanjem pri uvajanju novih tehnologij za delo $\mathrm{v}$ gozdu, skupnim upravljanjem $\mathrm{z}$ gozdovi, svetovanjem in podporo članom pri primarni predelavi lesa ter pomočjo zasebnim lastnikov gozda pri kalkulacijah stroškov. Med najmanj pomembna področja spadata skupno iskanje izvajalcev za opravljanje del v gozdu $(1,6 \%)$ in svetovanje ter podpora pri graditvi gozdnih prometnic $(3,2 \%)$.

Člani ZLGS so predlagali kar nekaj področij delovanja, ki bi jim ZLGS v prihodnje morala nameniti več pozornost. Pri tem pa lahko opazimo, da se vzorci potreb z lokalnega nivoja, torej ravni delovanja predvsem DLG (Leban, 2014), prenašajo na nacionalno raven torej $\mathrm{v}$ delovanje ZLGS. Tako v ospredje ponovno prihajajo področja delovanja ZLGS, ki so povezana s socialnimi vidiki povezovanja, torej z druženjem in izobraževanjem članov na vseh področjih gozdarstva (Leban, 2014). Prav tako člani v veliki meri kažejo željo po poslovnem sodelovanju z ZLGS, v smislu skupne prodaje GLS, saj so te aktivnosti na ravni lokalnih oblik povezovanja zasebnih lastnikov gozdov redke. $V$ Evropi so pri večini Zvez zasebnih lastnikov gozdov glavne naloge vezane predvsem na zastopanje interesov zasebnih lastnikov gozdov in aktivno sodelovanje pri oblikovanju in sprejemanju z gozdom povezane zakonodaje (CEPF, 2020). Oblike povezovanja zasebnih lastnikov gozdov na lokalnem nivoju pa se ukvarjajo predvsem s praktičnim zagotavljanjem učinkovitega gospodarjenja $\mathrm{z}$ gozdovi (svetovanje in izobraževanje svojih članov na vseh področjih gozdarstva in pomočjo pri prodaji GLS) (Kittredge, 2005; Šalka in sod., 2016; Kronholm, 2016; Hrib in sod., 2017). Možen razlog, zakaj je napredek v smeri poslovnega povezovanja med zasebnimi lastniki na lokalnem nivoju v Sloveniji tako redek, je zagotovo v pomanjkanju institucionalne podpore oblikam povezovanja na lokalnem nivoju, prav tako pa je problem finančna in kadrovska šibkost oblik povezovanja (Aurenhammer in sod., 2017).

\subsection{Trenutno stanje poslovnega sodelovanja na lokalnem nivoju}

4.2 Current state of business cooperation at the local level

Oblike povezovanja zasebnih lastnikov gozdov na lokalnem nivoju so bile ustanovljene iz različnih razlogov. Vsem pa je skupno, da si želijo izboljšati gospodarjenje v zasebnih gozdovih in omogočiti učinkovitejšo prodajo GLS. Ideja, da bi se lokalna združenja zasebnih lastnikov gozdov ali pa ZLGS ukvarjala s skupno prodajo GLS in iskanjem izvajalcev gozdarskih del, izhaja iz tujine, saj v mnogih evropskih državah lokalna združenja zasebnih lastnikov gozdov ponujajo svojim članom podporo/pomoč pri skupnem gospodarjenju z gozdovi in pri skupni prodaji GLS, le redko to počnejo Zveze zasebnih lastnikov gozdov (Weiss in sod., 2012; Šalka in sod., 2016; Hrib in sod., 2017). Zanimalo nas je, koliko oblik povezovanja zasebnih lastnikov gozdov na lokalnem nivoju daje svojim članom podporo/pomoč pri skupnem gospodarjenju z gozdom in za svoje člane omogoča koordinirano oziroma skupno prodajo GLS. Kot podporo/pomoč pri skupnem gospodarjenju z gozdom smo šteli organizirano, skupno gospodarjenje na več gozdnih posestih hkrat

Na lokalnem nivoju zgolj v Solastniški skupnosti »Planinca« Begunje na Gorenjskem ter SK Bled dajejo svojim članom podporo pri skupnem gospodarjenju $\mathrm{z}$ gozdovi, kar je podprto tudi z izjavo intervjuvanca: »Eden od članov ima podjetje za posek, spravilo in prodajo GLS in ves posel sam izpelje." [ORG 9].

Pri dajanju podpore pri koordinirani oziroma skupni prodaji GLS je aktivna slaba tretjina (29\%) oblik povezovanja zasebnih lastnikov gozdov na lokalnem nivoju. Poudarjajo, da ima koordinirana oziroma skupna prodaja GLS smisel, saj lahko zasebni lastniki gozdov dosegajo večje ekonomske donose iz gozda. Intervjuvanca sta povedala: »Smiselna je skupna prodaja GLS, saj lahko dosegamo boljše cene z večjimi količinami.« [ORG 10] in »Tako se doseže boljša cena, ker se naberejo večje količine GLS.« [ORG 22]. Kljub temu, da se članom ZLGS zdi koordinirana oziroma skupna prodaja GLS zelo smiselna, pa jih je kar nekaj to dejavnost $\mathrm{v}$ preteklosti opustilo, večinoma zaradi pomanjkanja kadra in časa. To potrjuje tudi izjava intervjuvanca: »Za skupni nastop na trgu GLS in poslovno sodelovanje smo zaenkrat v DLG kadrovsko in finančno prešibki.« [ORG 18]. Prav tako pa so postavili v ospredje problem nelojalnosti članov v smislu zagotavljanja GLS ob podpisu dolgoročnih pogodb z lokalnimi odkupovalci: »Problem je, da daš za nekoga roko v ogenj in se pogajaš za količine in cene ... potem pa morda niti ne moreš zagotoviti dogovorjene količine GLS, podpišeš pa pogodbo. Ni enostavno." [ORG 10].

Pričakovali bi, da bi bil delež članov ZLGS, ki pomagajo pri koordinirani oziroma skupni prodaji GLS, večji, saj je bil eden glavnih razlogov za ustanovitev oblik povezovanja zasebnih lastnikov gozdov na lokalnem nivoju ravno skupna prodaja GLS (Krajčič in Mori, 2006). Vendar pa se oblike povezovanja zasebnih lastnikov gozdov spoprijemajo s problemi, ki so povezani z ne- 
lojalnostjo članov v primeru podpisa dolgoročnih pogodb za odkup GLS, neaktivnostjo članov, profesionalizacijo delovanja in finančnimi težavami (Aurenhammer in sod., 2017; Pezdevšek Malovrh in Laktić, 2017). Raziskave tako doma kot v tujini kažejo, da si morajo oblike povezovanja zasebnih lastnikov gozdov lojalnost svojih članov prislužiti, saj ne morejo prisiliti člane, da GLS prodajo ravno njim, kar pa lahko dosežejo z zagotovitvijo dovolj visokih odkupnih cen za GLS (Wästerlund in Kronholm, 2017; Černač in Pezdevšek Malovrh, 2020). Nadalje Krajčič in Mori (2006) ugotavljata, da se, potem ko dejavnosti oblik povezovanja zasebnih lastnikov gozdov na lokalnem nivoju (predvsem DLG) prerastejo inicialno fazo, pojavlja vse več argumentov za njihovo profesionalizacijo. Torej so oblike povezovanja zasebnih lastnikov gozdov na lokalnem nivoju pri nas že na stopnji, ko bi morale prestopiti na profesionalno raven in bi svoj kader finančno pokrivale same. Problem pa se pojavi, ker oblike povezovanja zasebnih lastnikov gozdov na lokalnem nivoju nimajo dovolj prihodkov (financirajo se pretežno samo iz članarin in donacij), člani pa so v povprečju pripravljeni prispevati premalo za dejansko izvedbo profesionalizacije (raziskave kažejo, da so pripravljeni prispevati v povprečju do 40 € letno) oziroma niso pripravljeni nositi finančnega bremena profesionalizacije (Pezdevšek Malovrh in Laktić, 2017). Rešitev problema na lokalnem nivoju se kaže v prvi vrsti v vzpostavitvi trdnejših vezi in dolgoročnih pogodb med zasebnimi lastniki gozdov kot ponudniki GLS in lokalnimi predelovalci GLS, ki odkupujejo GLS za potrebe lastne proizvodnje (Sojč, 2018), pri čemer pa je pomembno, da se izboljšajo notranje organizacijske kapacitete DLG (Aurenhammer in sod., 2017) in da je poskrbljeno za ozaveščanje o ekonomskem povezovanju ter o prednostih skupne gozdne proizvodnje in trženja GLS (Breznikar in sod., 2017). Ker je glede na trenutno stanje verjetnost, da bo profesionalizacija v smislu poslovnega sodelovanja na lokalnem nivoju zaživela, majhna, se pojavlja priložnost da ZLGS prevzame iniciativo na tem področju, seveda ob pogoju, da se zagotovijo ustrezni finančni in kadrovski viri za njeno delovanje.

\subsubsection{Poslovno sodelovanje pri prodaji GLS}

\subsubsection{Business cooperation in timber sales}

Nadalje smo člane ZLGS, ki dajejo podporo članom pri skupni prodaji GLS, vprašali, na kakšen način organizirajo skupno prodajo GLS. V veliki večini primerov oblika povezovanja zasebnih lastnikov gozdov najde odkupovalca GLS v lokalnem okolju, ki potem neodvisno od oblike povezovanja odkupuje GLS od več članov: »Mi najdemo odkupovalca, ki mu damo pripo- ročilo in sam obišče člane, sam se pogaja za ceno. Vsak odkupovalec zase izda račun potem zasebnemu lastniku gozda.« [ORG 10], le redko pa se oblika povezovanja dogovarja z odkupovalci GLS in z njimi sklepa pogodbe: »DLG se je dogovorilo z avstrijskimi žagami za prodajo večjih količin GLS. « [ORG 15].

Premik v smeri poslovnega sodelovanja in vzpostavitve novih poslovnih modelov med člani ZLGS na lokalnem nivoju je redek. Do sedaj sta le dva člana ZLGS naredila premik $\mathrm{v}$ smeri poslovnega povezovanja in ustanovila profitno združenje. Tako so na primer posamezni člani DLG Pohorje - Kozjak ustanovili zadrugo za skupno prodaja GLS oziroma člani SK Bled gospodarsko družbo (SK Servis d. o. o.) za izvajanje storitev in prodajo GLS ter biomase. V tujini so tovrstni premiki združenj v smeri poslovnega sodelovanja pogostejši. Drugod po Evropi združenja za namene poslovnega sodelovanja pogosto ustanovijo zadruge in podjetja oziroma prilagodijo svoje delovanje (Kupčak, 2003; Kronholm, 2016; Hrib in sod., 2017). Na področju spodbujanja poslovnega sodelovanja zasebnih lastnikov gozdov pri nas, v Programu razvoja podeželja, obstaja možnost finančne podpore pri vzpostavitvi organizacij proizvajalcev, ki delujejo na pridobivanju GLS z dejavnostmi organiziranja gozdne proizvodnje, odkupa in prodaje GLS iz zasebnih gozdov ter povezovanje v proizvodne verige s primarno predelavo (Operativni program za izvajanje Nacionalnega gozdnega programa 20172021, 2017). Za zdaj se še nobena od oblik povezovanja zasebnih lastnikov gozdov na lokalnem nivoju ni odločila za takšno sodelovanje, saj so finančne podpore skromne v primerjavi s stroški, ki bi nastali zaradi zaposlitev ljudi, ki bi opravljali vse potrebno delo, kot je npr. prevzem GLS, sortiranje, priprava dokumentacije itd. (Hren, 2019).

\subsubsection{Poslovno sodelovanje pri izvedbi del v gozdu}

4.2.2 Business cooperation in the execution of forest works

Zaradi majhne in razdrobljene gozdne posesti, ki otežuje ekonomsko donosno gospodarjenje, slabega znanja o izvedbi del na varen in sodoben način ter pomanjkanja informacij se zasebni lastniki gozdov vse pogosteje odločajo, da s svojim gozdom ne bodo gospodarili ali pa da izvedbo del prepustijo izvajalcem gozdarskih storitev (Iveta, 2017). Da bi ugotovili, ali se člani ZLGS spopadajo s problemom iskanja izvajalcev gozdarskih del, ko se odločijo za poslovno povezovanje pri izvedbi del, smo le-te vprašali, ali jim na lokalnem nivoju uspe zagotoviti izvajalce za opravljanje gozdarskih del za člane organizacije oblike (slika 4). Rezultati so pokazali, da kar 79,2 \% članov ZLGS nima 


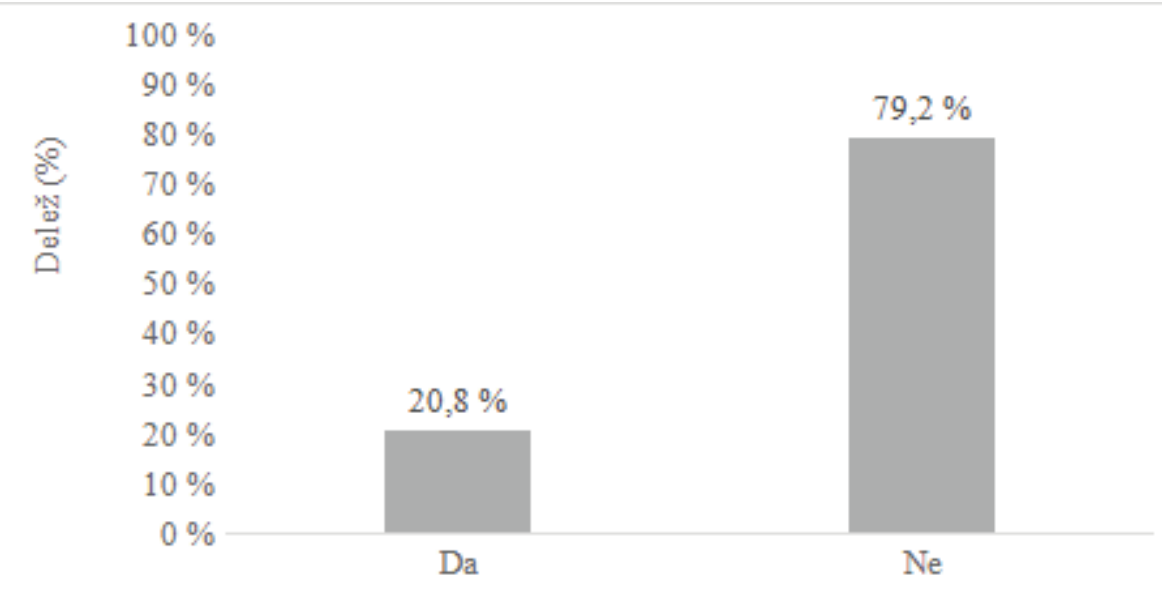

Slika 4: Spoprijemanje članov ZLGS s problemom iskanja izvajalcev del

problemov z iskanjem izvajalcev za delo v gozdu za svoje člane. Intervjuvanca sta povedala: »V okviru SK si pomagamo med sabo, delamo eden za drugega, ko je to potrebno." [ORG 19] in »Pri iskanju izvajalcev ni težav, ker si tudi glede tega v DLG veliko pomagamo« [ORG 11].

20,8 \% članov ZLGS ima probleme pri iskanju izvajalcev gozdarskih del za svoje člane. Ti nastajajo predvsem v primeru ujm, naravnih nesreč in pri napadih podlubnika, kar se kaže tudi v izjavah intervjuvancev: »Težave so, ko pride lubadar in ne dobimo izvajalcev za delo v gozdu.« [ORG 16] in »... problem imamo, ker so izvajalci sedaj zelo zaposleni zaradi ujm, lubadarja« [ORG 22]. Na območju ene izmed oblik povezovanja zasebnih lastnikov gozdov na lokalnem nivoju imajo težave, ker na celotnem območju delovanja oblike povezovanja zasebnih lastnikov gozdov nimajo kamiona za prevoz GLS: »Imamo problem, ker na območju DLG ni kamiona za prevoz GLS.« [ORG 16].

Raziskave tako doma kot v tujini so pokazale, da se spopadamo s problemom neaktivnosti zasebnih lastnikov gozdov, ki se pojavlja zaradi pomanjkanja znanja in interesa oziroma časa za delo v gozdu in zaradi neopremljenosti za delo v gozdu (Winkler in Medved, 1994; Ropret, 2007; Kronholm, 2016; Kumer, 2017). Naši rezultati nakazujejo ravno nasprotno, zato lahko sklepamo, da so člani lokalnih oblik povezovanja zasebnih lastnikov gozdov predvsem zasebni lastniki gozdov, ki so aktivni pri gospodarjenju in z gozdom gospodarijo sami. To potrjujejo tudi ugotovitve preteklih raziskav, kjer so ugotovili, da z velikostjo gozdne posesti in večjo pripravljenostjo za gospodarjenje $\mathrm{z}$ gozdom narašča pripravljenost zasebnih lastnikov gozdov za povezovanje v organizacijske oblike na lokalnem nivoju (Pezdevšek Malovrh, 2010; Pezdevšek Malovrh in Laktić, 2017). Težave pri aktivnih lastnikih gozda nastanejo v primeru naravnih nesreč, ko se pokaže primanjkljaj

Fig. 4: Addressing the problem of finding contractors for FOAS members

njihovega znanja za delo v gozdu v izrednih razmerah. Iveta (2017) je ugotovila, da je ravno sanitarna sečnja tista storitev, ki jo izvajalci gozdarskih storitev najpogosteje izvajajo.

4.3 Možnosti za poslovno sodelovanje in vzpostavitev novih poslovnih modelov med ZGLS in njenimi člani

4.3 Opportunities for business cooperation and the establishment of new business models between the FOAS and its members

4.3.1 Interes za poslovno sodelovanje znotraj oblik povezovanja zasebnih lastnikov gozdov na lokalnem nivoju

4.3.1 Interest in business cooperation within private forest owners associations at the local level

Oblike povezovanja zasebnih lastnikov gozdov na lokalnem nivoju imajo v svojih Statutih zapisane naloge, ki posegajo na področje poslovnega sodelovanja, torej delovanje $\mathrm{v}$ smeri skupnega iskanja izvajalcev del $\mathrm{v}$ gozdovih ter koordinirane oziroma skupne prodaje GLS. Zato nas je zanimalo, ali oblike povezovanja zasebnih lastnikov gozdov resnično izkazujejo interes za delovanje na področju poslovnega sodelovanja (slika 5). Rezultati kažejo, da kar 91,7 \% članov ZLGS izkazuje interes za poslovno sodelovanje v smeri skupnega iskanja izvajalcev del v gozdovih ter koordinirane oziroma skupne prodaje GLS, kar potrjujejo izjave intervjuvancev: »Bi bilo smiselno, da bi skupaj prodajali GLS, ker bi lahko zagotovili večje količine GLS." [ORG 22] in "Za manj vredne GLS in sekance bi bilo predvsem smiselno, da bi skupno prodajali; dober les ni bilo nikoli problem prodati, problem so slabša kvaliteta in sekanci.« [ORG 10]. Le 8,3 \% oblik povezovanja zasebnih lastnikov gozdov se poslovno sodelovanje v smeri skupnega iskanja izvajalcev del v gozdovih ter koordinirane ozi- 


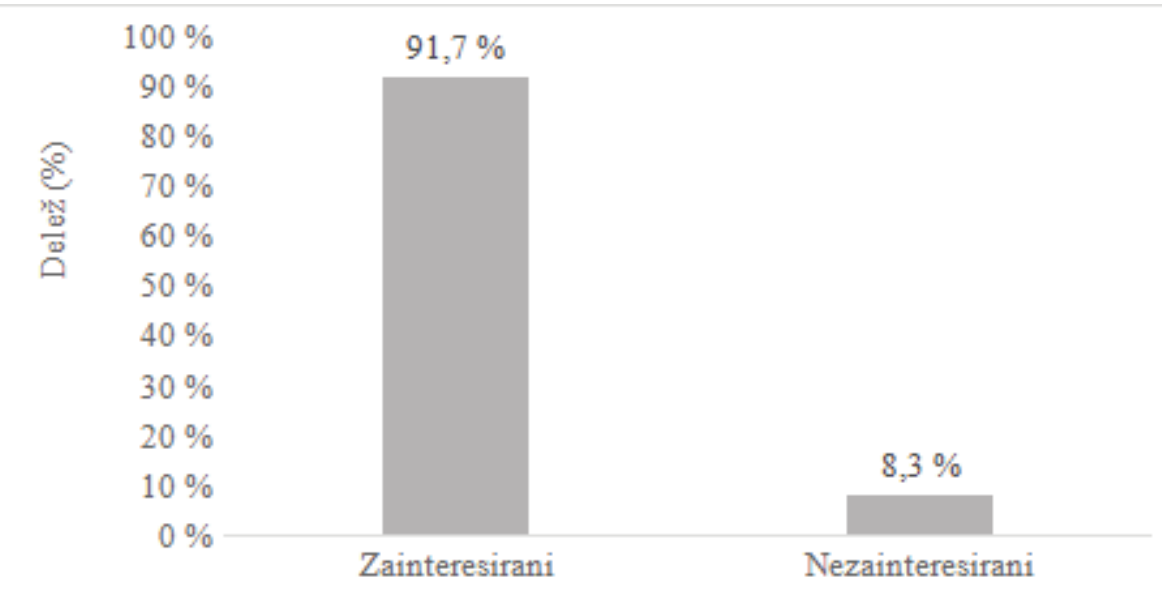

Slika 5: Izkazani interes oblik povezovanja zasebnih lastnikov gozdov na lokalnem nivoju za delovanje na področju poslovnega sodelovanja

roma skupne prodaje GLS ne zdi smiselno, kar potrjuje izjava intervjuvanca: "... predlog je že bil, da bi se bolj povezali na področju poslovnega sodelovanja, vendar lastniki gozdov nočejo stopiti skupaj ...« [ORG 1] in izjava: »Smo že razmišljali, da bi skupno prodajali kotlovnici lesne sekance, vendar se finančno ni izšlo." [ORG 23].

Eden izmed intervjuvanih je povedal, da ne vidijo potrebe po koordinirani oziroma skupni prodaji GLS, ker imajo člani oblike povezovanja zasebnih lastnikov gozdov že ustaljene poslovne odnose z lokalnimi odkupovalci GLS: »Ni tako slaba ideja o poslovnem sodelovanju, vendar mislim, da na našem območju to nima smisla, saj imamo dva, tri močne odkupovalce GLS v lokalnem okolju, s katerimi člani že sedaj dobro sodelujejo." [ORG 20]. Nekdo drug je mnenja, da je skupno iskanje izvajalcev za delo v gozdu smiselno predvsem za manjše gozdne posesti: »Pri nas ne čutimo potrebe po poslovnem sodelovanju, verjamem pa, da je kje drugje, kjer so gozdne posesti manjše, to zelo smiselno."[ORG 19].

Velika stopnja pripravljenosti za poslovno sodelovanje znotraj oblik povezovanja zasebnih lastnikov gozdov na lokalnem nivoju je bila pričakovana, saj so bile oblike povezovanja ustanovljene prav s tem namenom, hkrati pa imajo oblike povezovanja zasebnih lastnikov gozdov v lokalnem okolju že zgrajeno omrežje deležnikov, ki so pomembni za mobilizacijo lesa iz zasebnih gozdov (Breznikar in sod., 2017; Iveta, 2017). Mednje po raziskavi Breznikar in sod. (2017) sodijo gozdarska podjetja, ki se ukvarjajo z gozdno proizvodnjo, odkupom in prodajo lesa, kmetijsko gozdarske zadruge, SK ter lesno predelovalna podjetja. Kljub temu pa so aktivnosti s področja skupne izvedbe del v gozdovih ter prodaje GLS še vedno redkost. Torej obstaja širok prostor za nadaljnji razvoj dejavnosti lokalnih oblik povezovanja zasebnih lastnikov gozdov. Kot ugotavljajo Breznikar in sod. (2017), pa se lokalne obli-

Fig. 5: Expressed interest of private forest owners associations at the local level in operating in the field of business cooperation

ke povezovanja zasebnih lastnikov gozdov prepogosto srečujejo s problemom pomanjkanja informacij s področja proizvodnje in trženja GLS ter tudi primanjkljaja finančnih, materialnih, človeških in časovnih virov za uresničevanje teh nalog. Tako znova ugotovimo, da obstajajo odprte možnosti za ZLGS na področju poslovnega povezovanja s svojimi člani.

4.3.2 Pripravljenost članov ZLGS za finančno podporo profesionalizaciji delovanja ZLGS

4.3.2 Readiness of FOAS members to financilly support the professionalization of FOAS activities

$S$ ciljem, da bi zagotovili profesionalno raven delovanja ZLGS, ki bi lahko učinkovitejše opravljala svoje naloge in razširila svoje delovanje tudi v smeri poslovnega sodelovanja (npr. koordinirane oziroma skupne prodaja GLS), je potrebno, da se zagotovijo ustrezna finančna sredstva za delovanje, saj se ZLGS tako kot lokalne oblike povezovanja zasebnih lastnikov gozdov srečuje s primanjkljajem finančnih virov. Trenutno se ZLGS poleg nepovratnih sredstev od Agencije Republike Slovenije za kmetijske trge in razvoj podeželja v manjši meri financira tudi s članarinami. Članarina ZLGS znaša za vsakih 10 članov oblike povezovanja zasebnih lastnikov gozdov $10 €$ (kar pomeni npr. $100 €$ za 100 članov). Člane ZLGS smo zato vprašali, kakšno je njihovo mnenje o povečanju zneska članarine v ZLGS $\mathrm{z}$ namenom profesionalizacije njenega delovanja, predvsem v smeri novih oblik poslovnega sodelovanja med člani in ZLGS, torej koordinirane oziroma skupne prodaje GLS (slika 6).

Rezultati kažejo, da se večina članov ZLGS $(73,9$ \%) strinja s povišanjem trenutnega zneska članarine v ZLGS, da bi se le-ta profesionalizirala, kar potrjuje tudi izjava intervjuvanca: »Ko bodo člani videli korist, potem ne bo noben problem, da finančno prispevajo."[ORG 14]. 




Slika 6: Strinjanje članov ZLGS s povišanjem zneska članarine v ZLGS z namenom njene profesionalizacije

Večina jih je sicer navedla, da manjše zvišanje članarine ne bi bila težava, kar potrjuje izjava intervjuvanca: »Do kakšnih $20 \%$ ne bi bil problem.« [ORG 6].

Slaba tretjina članov ZLGS se s povišanjem zneska članarine ne strinja. Intervjuvanec je opozoril na to, da manjše povišanje članarine nima smisla, saj to še vedno ne bi bili zneski, ki bi pomenili veliko spremembo v proračunu ZLGS: »Tudi če bi za 100 \% povečali članarino, to še vedno ni dovolj. Poleg tega so ljudje na povišanje nekega zneska zelo občutljivi.« [ORG 22]. Ugotovimo torej, da povišanje članarine, na kakršno bi člani ZLGS bili pripravljeni privoliti, ni dovolj veliko, da bi se lahko iz tega naslova financirala profesionalizacija ZLGS. Prav tako je iz preteklih izkušenj razvidno, da člani ZLGS že obstoječi znesek članarine ZLGS težko poravnajo oziroma je vsi člani niti ne plačajo vsako leto (Hren, 2019). Kljub visoki pripravljenosti članov ZLGS, da finančno prek povišanja članarine podprejo profesionalizaciji delovanja ZLGS, lahko zaključimo, da le-to ne bi rešilo problema financiranja in omogočilo profesionalizacijo delovanja ZLGS. Zato je pomembno, da si ZLGS zagotovi financiranje iz lastnih poslovnih aktivnosti, kakršna je praksa v tujini (Weiss in sod., 2012).

4.3.3 Stopnja pripravljenosti članov ZLGS za poslovno sodelovanje pri prodaji GLS in ocena primernosti predlaganih poslovnih modelov

4.3.3 Degree of willingness of FOAS members for business cooperation in timber sales and assessment of the suitability of the proposed business models

Pri članih ZLGS in v upravnem odboru ZLGS je že bilo slišati pobude za nove oblike poslovnega sodelovanja med člani in ZLGS. Ideja je, da bi ZLGS organizirala koordinirano oziroma skupno prodajo GLS za svoje
Fig. 6: Consent of FOAS members to increase the FOAS membership fee in order to professionalize it

člane. Pri skupni prodaji bi ZLGS morala ustanovitvi gospodarsko družbo oziroma zadrugo, da bi lahko legalno opravljala storitev prodaje GLS. Prek gospodarske družbe oziroma zadruge bi si ZLGS kot plačilo za opravljeno delo obračunala delež od vsakega prodanega $\mathrm{m}^{3}$ GLS. Sojč (2018) in Černač (2019) sta ugotovila, da je za tovrstno sodelovanje pri nas najprimernejši zadružni sistem zaradi dolge tradicije zadružništva. Tuje raziskave in primer dobre prakse pri nas (npr. SK Servis d.o.o.) pa so pokazale, da se poleg zadrug zelo pogosto ustanavljajo tudi gospodarske družbe, ki imajo v primerjavi z zadrugami dve ključni prednosti, in sicer, da ob včlanitvi v gospodarsko družbo članu ni treba prispevati določenega (obveznega) članskega deleža in da je v zadrugi precej težje prejemati in doseči odločitve zaradi možnega zaviralnega delovanja posameznih članov pri opravljanju gospodarske dejavnosti (Kupčak, 2003; Breznikar in sod., 2017). Druga možnost poslovnega sodelovanja med ZLGS in njenimi člani je v obliki koordinirane prodaje, kar bi pomenilo, da ZLGS najde samo odkupovalce GLS, se z njimi dogovori za odkup, podpiše dolgoročno pogodbo in se dogovori za cene GLS, odkupovalec pa potem pri vsakem posameznem zasebnemu lastniku gozda, ki je član oblike povezovanja zasebnih lastnikov gozdov na lokalnem nivoju, odkupi GLS. ZLGS v tem primeru ne bi bilo treba ustanoviti gospodarske družbe oziroma zadruge, saj bi bila le v vlogi organizatorja oziroma koordinatorja. Svoje plačilo za opravljeno storitev pa bi prejela kot delež od prodanega $\mathrm{m}^{3}$ GLS od svojih članov v obliki članarine, ki bi se lahko plačevala tudi večkrat letno. Da bi predstavljena modela poslovnega sodelovanja zaživela, je nujno, da so člani ZLGS za tovrstno sodelovanje pripravljeni (slika 7). Kar 73,9 \% članov ZLGS je zainteresiranih za poslovno sodelovanje pri 


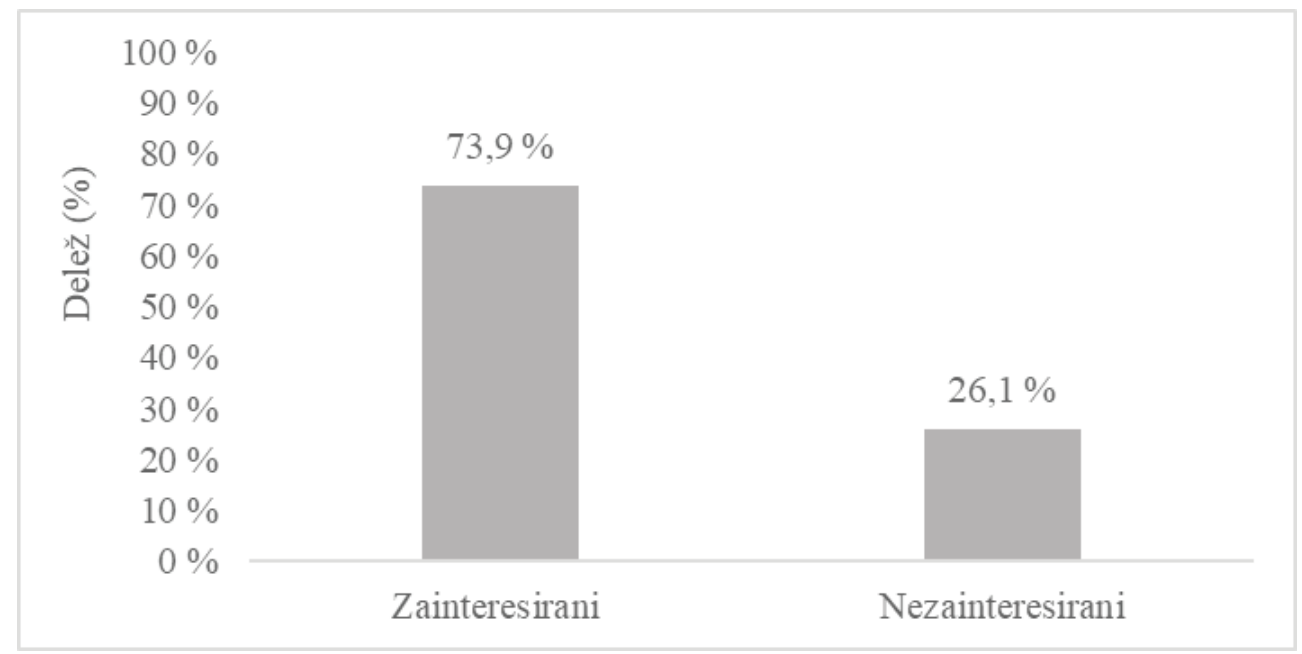

Slika 7: Stopnja zainteresiranosti članov ZLGS za poslovno sodelovanje pri prodaji GLS

prodaji GLS, 26,1 \% pa ne. Intervjuvanec je povedal: „Če gledam osebno, kot lastnik gozda, se mi skupna/koordinirana prodaja ne zdi smiselna, ker sem večji lastnik in sam obvladam trg, če pa se postavim v kožo manjšega lastnika gozda, pa je skupna/koordinirana prodaja zelo smiselna.« [ORG 10].

Rezultati o visoki stopnji pripravljenosti članov ZLGS za nove oblike poslovnega sodelovanja z ZLGS niso presenetljivi, saj so dosedanje raziskave o problemih, s katerimi se srečujejo zasebni lastniki gozdov pri prodaji GLS, ugotovile, da so le-ti povezani z nizkimi cenami, problemom plačilne nediscipline, plačilnimi roki in nezanesljivostjo odkupovalcev GLS (Pezdevšek Malovrh in Laktić, 2017; Sojč, 2018; Černač in Pezdevšek Malovrh, 2020), hkrati pa je tovrstno poslovno sodelovanje na lokalnem nivoju znotraj oblik povezovanja redko (Breznikar in sod., 2017). Tudi druge raziskave o pripravljenosti zasebnih lastnikov gozdov za
Fig. 7: Level of interest of FOAS members in business cooperation in timber sales

poslovno sodelovanje so pokazale, da je za predhodno povezovanje in nato poslovno sodelovanje pripravljeno kar nekaj lastnikov gozdov (npr. na primeru revirja Vodice kar 40,0 \% lastnikov iz raziskave) (Iveta, 2017), kar govori v prid tovrstnim poslovnim modelom.

Nadalje smo člane, ki so izrazili interes za poslovno sodelovanje z ZLGS, vprašali, kateri poslovni model sodelovanja se jim zdi bolj primeren: koordinirana ali skupna prodaja GLS (slika 8). Člani ZLGS so mnenja, da je koordinirana prodaja GLS bolj smiselna kot skupna prodaja GLS. Menijo, da je koordinirana prodaja boljša zato, ker je smiselno, da ZLGS nima stika s finančnimi tokovi, ki potekajo med prodajalci (zasebnimi lastniki gozdov) in odkupovalci GLS, ter da so računi ločeni za vsakega lastnika gozda posebej. Intervjuvanca sta povedala: „ZLGS, če bi šla $v$ to, ne bi smela imeti nič z denarjem, ker se lahko hitro zalomi, zato je boljše, da samo koordinira prodajo. [ORG 19] in »Koordinirana prodaja



Slika 8: Primernost predlaganih poslovnih modelov sodelovanja pri prodaji GLS
Fig. 8: Suitability of the proposed business models of cooperation in timber sales 
se mi zdi boljša, da so računi ločeni.« [ORG 17]. Tisti člani ZLGS, ki menijo, da je skupna prodaja GLS boljša od koordinirane, navajajo, da je ta bolj transparentna in bolj zanimiva za kupca GLS, kar potrjujeta izjavi intervjuvancev: »Boljša se mi zdi skupna prodaja, saj bi bilo to veliko bolj funkcionalno in transparentno." [ORG 12] in »Boljša se mi zdi skupna prodaja, ker je tako lažje za kupca in je tudi bolj pregledna."[ORG 6].

Če bi ZLGS želela stopiti na pot poslovnega sodelovanja s svojimi člani in začeti s koordinirano oziroma skupno prodajo GLS, bi to pomenilo, da bi morali člani ZLGS za to storitev plačati določen delež od vsakega prodanega $\mathrm{m}^{3} \mathrm{GLS}$. Zanimalo nas je, koliko bi bili po oceni intervjuvancev zasebni lastniki gozda kot prodajalci GLS pripravljeni prispevati za organizacijo koordinirane oziroma skupne prodaje GLS s strani ZLGS, oziroma koliko menijo, da bi lastniki gozdov s tovrstno koordinirano oziroma skupno prodajo GLS pridobili pri ceni GLS. Intervjuvanci mislijo, da bi bili zasebni lastniki gozdov pripravljeni prispevati v povprečju 3,3 $\%$ od prodajne cena na $\mathrm{m}^{3}$ GLS za koordinirano oziroma skupno prodajo, pri čemer je bil najnižji navedeni odstotek $1,5 \%$ od prodajne cene na $\mathrm{m}^{3} \mathrm{GLS}$ ter najvišji odstotek $10 \%$ od prodajne cene na $\mathrm{m}^{3} \mathrm{GLS}$. Eden od intervjuvanih je poudaril, da je pomembno, da člani najprej vidijo dober rezultat, torej višje odkupne cene za GLS, šele potem bodo pripravljeni prispevati nekaj za koordinirano oziroma skupno prodajo GLS: »Noben ne bo plačal nič, ko bo pa rezultat, bodo plačali, kolikor bo treba. Vendar brez rezultata ne bo nič.» [ORG 19]. Intervjuvanci v povprečju menijo, da bi zasebni lastniki gozdov s koordinirano oziroma skupno prodajo pridobili $14,4 \%$ pri prodajni ceni GLS, pri čemer je bil najnižji navedeni odstotek $5 \%$ in najvišji $30 \%$.
Analiza posameznih primerov dobrih praks tako doma kot $v$ tujini je pokazala, da zasebni lastniki gozdov, ki skupaj nastopajo na trgu prek oblik povezovanja na lokalnem nivoju, dosegajo v povprečju boljše odkupne cene $\mathrm{v}$ primerjavi $\mathrm{z}$ nepovezanimi lastniki (Põllumäe in sod., 2016; Černač in Pezdevšek Malovrh, 2020; Nilsson in sod., 2020). Pri analizi odkupnih in prodajnih cen $\mathrm{v}$ gozdarski zadrugi lastnikov gozdov Pohorje - Kozjak sta Černač in Pezdevšek Malovrh (2020) ugotovila, da je s povezovanjem lastnikov gozdov pri prodaji GLS možno iztržiti več, kot če bi lastniki GLS nastopali na trgu posamezno. V obdobju od 2013 do 2017 so bile odkupne cene v analizirani zadrugi za 9,98 eur $/ \mathrm{m}^{3}$ višje od povprečnih slovenskih cen. Tudi Krajčič in Mori (2006) sta ugotovila, da bi z združevanjem lastnikov v DLG Mirnske doline pri skupni prodaji GLS dosegali okoli 5 \% višje cene na trgu GLS, kot če bi vsak zasebni lastnik gozda prodajal GLS sam zase.

Novi poslovni modeli sodelovanja ZLGS z njenimi člani $v$ smislu koordinirane oziroma skupne prodaje GLS nedvomno prinašajo pomembne koristi za člane ZLGS, hkrati pa bi lahko primeri dobrih praks spodbudili zanimanje nepovezanih zasebnih lastnikov gozdov za članstvo $\mathrm{v}$ oblikah povezovanja lastnikov gozdov na lokalnem nivoju, ki so člani ZLGS. Kot je bilo pričakovati, večina $(87,0 \%)$ intervjuvanih meni, da bi novi poslovni modeli sodelovanja ZLGS s člani povečali zanimanje nepovezanih zasebnih lastnikov gozdov za članstvo $v$ oblikah povezovanja zasebnih lastnikov gozdov na lokalnem nivoju, ki so člani ZLGS (slika 9), pri čemer jih je večina navedla, da bi se to zgodilo le, če bi bili vidni dobri rezultati, torej doseganje višjih cen za GLS kot sicer. To potrjujeta tudi izjavi intervjuvancev: "Ja, če bi se pokazale dobre prakse, da dosegamo dobre

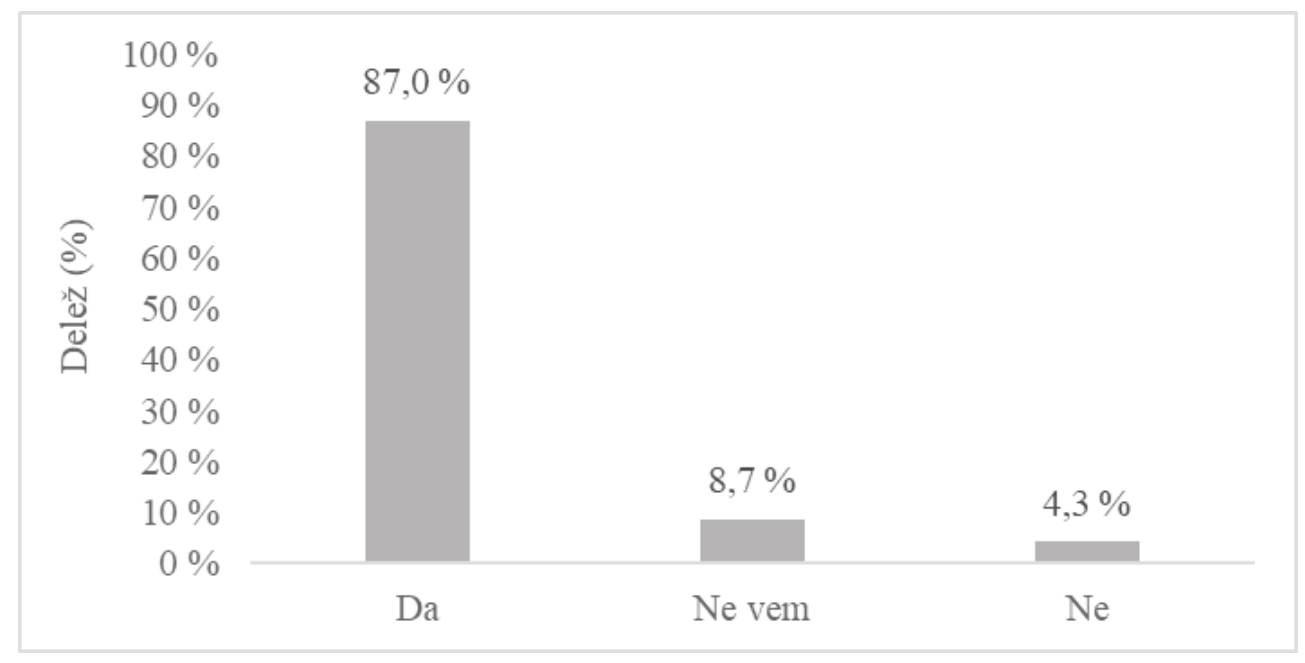

Slika 9: Povečanje zanimanja za članstvo v oblikah povezovanja lastnikov gozdov na lokalnem nivoju na podlagi primera dobrih praks poslovnega sodelovanja
Fig. 9: Increasing interest in membership in private forset owners associations at the local level based on examples of good practises of business cooperation 
rezultate."[ORG 23] in »Bi se povečalo zanimanje, ker je ekonomska plat gospodarjenja z gozdom za lastnike vedno najbolj zanimiva." [ORG 18].

Nekaj (8,7 \%) intervjuvanih je navedlo, da ne vedo, ali bi novi poslovni modeli povečali zanimanje nepovezanih lastnikov gozdov za članstvo v oblikah povezovanja lastnikov gozdov, 4,3\% intervjuvanih pa jih meni, da novi poslovni modeli ne bi povečali zanimanja za članstvo. Neki intervjuvanec je povedal: »Ne, v našem koncu so tisti, ki bi jim prišlo to prav, že včlanjeni v SK." [ORG 20].

\section{ZAKLJUČKI IN SMERNICE ZA VZPOSTAVITEV NOVIH POSLOVNIH MODELOV}

5 CONCLUSIONS AND GUIDELINES FOR THE ESTABLISHMENT OF NEW BUSINESS MODELS

V Sloveniji se na lokalnem nivoju zasebni lastniki gozdov najpogosteje povezujejo $v$ neprofitna združenja, in sicer v DLG, ki največ pozornosti v svojem delovanju posvečajo izobraževanju, informiranju članov in organiziranju ekskurzij ter dogodkov. Oblike povezovanja na lokalnem nivoju se na nacionalni ravni povezujejo v ZLGS, katere glavni namen je zastopanje interesov svojih članov (Pezdevšek Malovrh, 2010).

Člani ZLGS so v raziskavi izkazali zadovoljstvo z delom ZLGS, predvsem zaradi njene vključenosti v politične procese oziroma $v$ procese sprejemanja zakonodaje, povezane z gozdovi in njihovim gospodarjenjem.

V prihodnje bi si člani ZLGS želeli sodelovanja z ZLGS $\mathrm{v}$ okviru novih poslovnih modelov, predvsem $\mathrm{v}$ smeri povezovanja pri prodaji GLS. Obenem si člani v prihodnje želijo, da ZLGS razširi svoje delovanje na naloge, povezane s socialnimi vidiki povezovanja, kot so strokovne ekskurzije, izobraževanja in pomoč pri kandidiranju na gozdarskih razpisih, torej so v ospredju še vedno socialni vidiki povezovanja in ne ekonomski vidiki, kot je to značilno za večino oblik povezovanja v tujini. Izobraževanje in usposabljanje zasebnih lastnikov gozdov (prek delavnic, predavanj, ekskurzij, študijskih krožkov) je ena izmed glavnih nalog javne gozdarske službe v Sloveniji (Zavoda za gozdove Slovenije) s področja svetovanja zasebnih lastnikov gozdov (Zakon o gozdovih, 1993). Sklepamo lahko, da Zavod za gozdove Slovenije na tem področju v celoti ne zadovoljuje potreb oziroma povpraševanja s strani zasebnih lastnikov gozda. Posledično se zasebni lastniki gozdov povezujejo v oblike povezovanja (predvsem DLG), da bi zadovoljili te potrebe, $\mathrm{v}$ manjši meri pa se povezujejo $\mathrm{v}$ združenja z gospodarskimi interesi. Hkrati pa je smer delovanja lokalnih DLG velikokrat usmerjena s strani zaposlenih na Zavodu za gozdove Slovenije, saj imajo le-ti po ugotovitvah Šinka (2012) in Breznikarja in sod. (2017), najpomembnejšo vlogo pri ustanavljanju in delovanju oblik povezovanja zasebnih lastnikov gozdov na lokalnem nivoju, kar se kaže v njihovem delovanju.

Glede na to, da se ZLGS spoprijema s problemom nestalnih finančnih sredstev in profesionalizacijo delovanja, smo raziskali nekaj možnosti za njeno profesionalizacijo in s tem bolj učinkovitejše delovanje. Tudi Pezdevšek Malovrh (2010) je opozorila na to, da je profesionalizacija dela ZLGS priložnost in da je ta izvedljiva v primeru, da bi ZLGS pridobila stalna finančna sredstva predvsem z različnimi podjetniškimi aktivnostmi, kar bi lahko bila tudi koordinirana oziroma skupna prodaja GLS. S tem ko bi ZLGS pridobila stalen finančen vir, kar bi imelo za posledico možnost povečanja kadrovskih kapacitet, bi lahko poleg mogočih novih aktivnosti bolje opravljala tudi svojo primarno nalogo zastopanje zasebnih lastnikov gozdov v procesih sprejemanja zakonodaje.

Naša raziskava je pokazala smiselnost poslovnega sodelovanja med ZLGS in njenimi člani v okviru novih poslovnih modelov, saj smo v prvi vrsti ugotovili, da trenutno zgolj tretjina članov ZLGS dejansko deluje na področju zagotavljanja pomoči pri prodaji GLS svojim članom. Tukaj vidimo priložnost za ZLGS, da kot krovna organizacija začne delati $\mathrm{v}$ smeri poslovnega povezovanja pri prodaji GLS in tako omogoči članom oblik povezovanja na lokalnem nivoju, da z njeno pomočjo uspešnejše nastopajo na trgu GLS.

Članom ZLGS se zdi najprimernejši poslovni model prodaje GLS koordinirana prodaja GLS. Po njihovem mnenju bi pri koordinirani prodaji ZLGS zgolj organizirala prodajo GLS, tako da najde odkupovalca GLS in z njim podpiše dolgoročno pogodbo in se dogovori za cene, plačilne pogoje ter koordinira prodajo. Finančni tokovi med zasebnim lastnikom gozda in odkupovalcem pa so ločeni za vsak sklenjeni posel posebej. Financiranje koordinirane prodaje bi bilo po naših ugotovitvah najbolj smiselno $\mathrm{v}$ obliki deleža od vsakega prodanega $\mathrm{m}^{3} \mathrm{GLS}$ (povprečno so pripravljeni plačati $3,3 \%$ od prodajne cene GLS).

Glede na rezultate, ki smo jih pridobili v raziskavi, smo oblikovali smernice za uresničitev poslovnega sodelovanja med ZLGS in njenimi člani. Smernice se nanašajo na koordinirano prodajo GLS, ki je bila s strani članov ZLGS prepoznana kot najprimernejša oblika poslovnega modela, kjer je treba v prvi vrsti opredeliti aktivnosti in deležnike. Za začetek vzpostavitve novega poslovnega modela koordinirane prodaje je potrebno naslednje:

- Promocija koordinirane prodaje med zasebnimi lastniki gozdov: ZLGS in oblike povezovanja na lokal- 
nem nivoju bi morale ozaveščati zasebne lastnike gozdov kot potencialne ponudnike GLS o prednostih poslovnega sodelovanja pri prodaji GLS in jim predstaviti poslovni model koordinirane prodaje.

- Pri ZLGS zagotoviti kader za delo na koordinirani prodaji: ZLGS bi za krajše časovno obdobje lahko samo financirala zaposlitev usposobljenega kadra, s specifičnimi znanji in spretnostmi, ki bi organiziral koordinirano prodajo GLS in kateremu bi zaupali tako ponudniki GLS (zasebni lastniki gozda), kot tudi odkupovalci GLS (lesna industrija, gozdarska podjetja). Na daljši časovni rok pa bi ZLGS kader financirala iz prihodkov z naslova koordinirane prodaje.

- Vzpostavitev vezi med deležniki: ZLGS in njeni člani morajo poskrbeti za podpis dolgoročnih pogodb med ponudniki GLS in odkupovalci GLS, kjer bi se ZLGS v imenu svojih članov pogajala za cene GLS in plačilne pogoje ter koordinirala prodajo. Pri tem je pomembno, da se v poslovni model vključijo zaupanja vredni in zanesljivi ponudniki in odkupovalci GLS, saj je predvideno, da finančni tokovi potekajo le med njimi.

- Pilotni poskus izvedbe poslovnega modela: ZLGS bi s pomočjo oblik povezovanja na lokalnem nivoju vzpostavila pilotno področje, na območju, kjer že obstajajo primeri dobrih praks sodelovanja med ponudniki in odkupovalci GLS, s ciljem ugotoviti, kje so možnosti za izboljšave $\mathrm{v}$ predlaganem poslovnem modelu. Pilotni poskus izvedbe poslovnega modela bi rabil za promocijo koordinirane prodaje med zasebnimi lastniki gozdov.

Po mnenju članov ZLGS bi novi poslovni modeli pri prodaji GLS v primeru dobrih rezultatov pri zasebnih lastnikih gozda povečali zainteresiranost za članstvo v oblikah povezovanja na lokalnem nivoju, hkrati pa bi s tem mobilizirali zasebne lastnike gozdov in s tem gozdne lesne vire. Poslovni modeli pri prodaji GLS bi zasebnim lastnikom gozdov zagotovili večje donose prek višjih prodajnih cen GLS. Koristi od novih poslovnih modelov prodaje GLS bi imela tudi lesno predelovalna industrija, saj bi poslovni modeli zagotavljali večje količine GLS na trgu in hkrati s sklenjenimi dolgoročnimi pogodbami tudi stalen vir surovine. Posledično bi se zaradi mobilizacije zasebnih lastnikov gozdov potem povečalo tudi število članov v ZLGS, kar pomeni, da bi se na tak način povečala moč ZLGS, ne samo v političnem procesu, marveč tudi na poslovnem področju. Večje število članov bi prineslo več prihodkov od koordinirane GLS in tako tudi dolgoročno večjo finančno stabilnost ZLGS.
Glede na trend, ki kaže v smeri prihodnje spremenjene lastniške strukture zasebnih gozdov, je pomembno, da razumemo, kako lastniki sami zaznavajo lastništvo gozdov in kakšen je njihov odnos do gospodarjenja. Le tako bomo lahko v okviru oblik povezovanja zasebnih lastnikov gozdov na lokalnem in državnem nivoju razvili poslovne modele sodelovanja in storitve, ki bodo zadovoljevale lastnikove potrebe (Matilainen in sod., 2019).

\section{POVZETEK}

\section{SUMMARY}

Private forests in Slovenia are characterized by small-scale and fragmented forest properties owned by a large number of owners who are generally old and independent of forest income and who lack knowledge and information about forest management. Consequently, these forests are difficult, and sometimes even impossible, to manage proportionately. The solution to at least some of these problems should ensure cooperation between private forest owners in various forms of organization. In recent times, private forest owners most often belong to non-profit associations of private forest owners at the local level and to the Forest Owners Association of Slovenia (FOAS) at the national level.

As the FOAS is confronted with the problem of nonpermanent financial resources and professionalization of its work, its activities are limited to certain tasks, the most important of which is the representation of private forest owners in the implementation of forest-related legislation. In order to improve the operation of the FOAS and to provide economic benefits to its members, the study analyzed the current operation of the FOAS and the willingness of its members for business cooperation with the FOAS, with the aim of establishing new business models.

We conducted in-depth personal interviews with representatives of private forest owners associations at the local level in order to obtain information on members' views of the FOAS, on ways of establishing business cooperation between the FOAS and its members, and on new business models.

The study shows that FOAS members are satisfied with the work of the FOAS, mainly because of its participation in political processes and in processes for adopting laws relating to forests and their management. In the future the members of the FOAS would like to work with the FOAS in the development of new business models, especially in cooperation in the sale of timber. At the same time, the members would like the FOAS to extend its activities in the future to include 
tasks related to the social aspects of cooperation, such as the organization of professional excursions, training and assistance in applying for forest tenders, so that the social aspects of operations continue to be more important than the economic aspects typical of most forms of private forest owners' associations abroad.

FOAS members find coordinated timber sales to be the most suitable business model for timber sales. In their opinion, in a coordinated sale, the FOAS would simply organize the sale of timber by finding a buyer for the timber and concluding a long-term contract with him, agreeing prices and payment terms, and coordinating the sale. The cash flows between the private forest owner and the buyer are separate for each concluded transaction. According to our findings, the most sensible way to finance a coordinated sale would be in the form of a share of each $\mathrm{m}^{3}$ of timber sold (on average, FOAS members are prepared to pay $3.3 \%$ of the timber sales price). Based on the results of the resear$\mathrm{ch}$, the guidelines for the realization of business cooperation between the FOAS and its members were developed. The guidelines refer to the coordinated sale of timber, which has been recognized by the FOAS members as the most appropriate form of business model where activities and stakeholders have to be defined first. The following is required to start setting up a new business model of coordinated sales:

- Promotion of coordinated sales among private forest owners: FOAS and the private forest owners associations at the local level should make private forest owners, as potential timber suppliers, aware of the advantages of business cooperation in timber sales and present a business model of coordinated sales.

- Provision of personnel to work in the FOAS in the area of coordinated sales: The FOAS could finance the employment of personnel who would organize the coordinated sale of timber for a short period only. It is important to employ personnel with specific skills and who are trusted by both the timber suppliers (private forest owners) and the timber buyers (timber industry, forest enterprises). In the long term, the FOAS would finance the personnel from the income from coordinated sales.

- Building stakeholder relationships: The FOAS and its members should arrange for the signing of longterm contracts between timber suppliers and timber buyers, in which the FOAS would negotiate timber prices and payment terms and coordinate sales on behalf of its members. It is important to include trustworthy and reliable suppliers and buyers of wood in the business model, as financial flows sho- uld only take place between them.

- Pilot test for the implementation of a business model: FOAS, with the help of private forest owners associations at the local level, would set up a pilot area in an area where there are already examples of good practices of cooperation between timber suppliers and buyers, in order to identify opportunities for improvement of the proposed business model. The pilot test area to implement a business model would serve to promote coordinated sales among private forest owners.

\section{ZAHVALA}

\section{ACKNOWLEDGEMENTS}

Za informacije o delovanju in ciljih ZLGS ter konstruktivne predloge, se iskreno zahvaljujemo predsedniku ZLGS, Marjanu Hrenu in strokovnemu tajniku ZLGS, Mihaelu Koprivnikarju. Hvala ZLGS, ki je finančno omogočila opravljanje intervjujev na terenu. Prav tako gre zahvala vsem intervjuvanim članom ZLGS za njihovo pripravljenost za sodelovanje v raziskavi.

\section{VIRI}

\section{REFERENCES}

Aurenhammer K.P., Ščap Š., Triplat M., Krajnc N. 2017. Actors' potential for change in Slovenian forest. Small-scale Forestry, 17: 165-189.

Breznikar A., Krajnc N., Ščap Š., Cojzer M. 2017. Priročnik za krepitev gozdarskega svetovanja na področju mobilizacije gozdnih lesnih virov v Sloveniji. Ljubljana, Zavod za gozdove Slovenije, Gozdarski inštitut Slovenije: 85 str.

CEPF. 2020. Estonia. Brussels, Confederation of European Forest Owners. http://www.cepf-eu.org/page/estonia (26. 2. 2020).

Černač G. 2019. Analiza uspešnosti prodaje gozdnih lesnih sortimentov v gozdarski zadrugi lastnikov gozdov Pohorje - Kozjak: diplomsko delo. (Univerza v Ljubljani, Biotehniška fakulteta, Oddelek za gozdarstvo in obnovljive gozdne vire). Ljubljana, samozal.: 37 str.

Černač G., Pezdevšek Malovrh Š. 2020. Analiza uspešnosti prodaje gozdnih lesnih sortimentov v gozdarski zadrugi lastnikov gozdov Pohorje - Kozjak. Zbornik gozdarstva in lesarstva, 122: 1-17.

Dobšinska Z., Živojinović I., Nedeljković J., Petrović N., Jarsky V., Vilem J., Oliva J., Šalka J., Sarvašova Z., Weiss G. 2020. Actor power in the restitution processes of forests in three European countries in transition. Forest Policy and Economics, 113, 102090: 15 str.

Fabra-Crespo M., Rojas-Briales E. 2015. Comparative analysis on the communication strategies of the forest owners' associations in Europe. Forest Policy and Economics, 50: 20-30.

Field A. 2018. Discovering Statistics Using IBM SPSS Statistics. $5^{\text {th }}$ ed. London, Sage publications: 816 str.

Glück P., Avdibegović A., Cabaravdić A., Nonić D., Petrović N., Posavec S., Stojanovska M. 2010. The preconditions for the formation of private forest owners' interest associations in the Western Balkan Region. Forest Policy and Economics, 12: 250-263.

Hren M. 2019. Delovanje Zveze lastnikov gozdov Slovenije. Ljubljana, Zveza lastnikov gozdov Slovenije (osebni vir, 16. 12. 2019).

Hrib M., Slezova H., Jarkovska M. 2017. To join small-scale forest owners' associations or not? Motivations and opinions of smallscale forest owners in three selected gegions of the Czech Republic. Small Scale Forestry, 17: 147-164 
Iveta N. 2017. Ocena pripravljenosti zasebnih lastnikov gozdov za poslovno sodelovanje pri gospodarjenju z gozdom na primeru revirja Vodice: magistrsko delo. (Univerza v Ljubljani, Biotehniška fakulteta, Oddelek za gozdarstvo in obnovljive gozdne vire). Ljubljana, samozal.: 137 str.

Kittredge D.B. 2005. The cooperation of private forest owners on scale larger than one individual property. Forest Policy and Economics, 7: 671-688.

Krajčič D., Mori J. 2006. Profesionalizacija dela društev lastnikov gozdov. Gozdarski vestnik, 64: 168-173.

Krippendorff K. 2004. Content analysis: an introduction to its methodology. 2nd ed. Thousand Oaks, CA, Sage Publications: 413 str. Kronholm T. 2016. How are Swedish forest owners' associations adapting to the needs of current and future members and their organizations?. Small-scale Forestry, 15: 413-432.

Kumer P. 2017. Vpliv družbenogeografskih dejavnikov na gospodarjenje z majhnimi zasebnimi gozdnimi posestmi: doktorska disertacija. (Univerza v Ljubljani, Filozofska fakulteta). Ljubljana, samozal.: 134 str.

Kupčak V. 2003. Economic analysis of forest joint-stock companies in the Czech Republic in 1992-2000. Journal of Forest Science, 49: 27-36.

Leban V. 2014. Analiza učinkovitosti delovanja društev lastnikov gozdov v Sloveniji in Nemčiji: magistrsko delo. (Univerza v Ljubljani, Biotehniška fakulteta, Oddelek za gozdarstvo in obnovljive gozdne vire). Ljubljana, samozal.: 129 str.

Matilainen A., Koch M., Živojinović I., Lähdesmäki M., Lidestav G., Karppinen H., Didolot F., Jarsky V., Põllumäe P., Colson V., Hricova Z., Glavonjić P., Scriban R.E. 2019. Perceptions of ownership among new forest owners - a qualitative study in European context. Forest Policy and Economics, 99: 43-51.

Medved M., Matijašić D., Pisek R. 2010. Private property conditions of Slovenian forests in 2010 (preliminary results). V: Small scale forestry in a changing world: opportunities and challanges and the role of extension and technology transfer: proceeding of the conference/ IUFRO Conference, 06-12 June, 2010, Bled, Slovenia. Medved M. (ur.). Ljubljana, Slovenian Forestry Institute, Slovenian Forest Service: $457-473$.

Neuendorf K.A. 2002. The content analysis guidebook. Thousand Oaks, Calif., Sage Publications: 456 str.

Nilsson J., Helgesson M., Rommel J., Svensson E. 2020. Forest-owner support for their cooperative's provision of public goods. Forest Policy and Economics, 115, 102156: 10 str..

Operativni program za izvajanje Nacionalnega gozdnega programa 2017-2021. 2017 http://www.mkgp.gov.si/fileadmin/mkgp.gov.si/ pageuploads/podrocja/Gozdarstvo/17_08_21_OPNGP_koncna.pdf (28. 9. 2020).

Pezdevšek Malovrh Š. 2010. Vpliv institucij in oblik povezovanja lastnikov gozdov na gospodarjenje z zasebnimi gozdovi: doktorska disertacija. (Univerza v Ljubljani, Biotehniška fakulteta). Ljubljana, samozal.: 224 str.

Pezdevšek Malovrh Š., Hodges G.D., Marić B., Avdibegović M. 2011. Private forest owner expectations of interest associations: comparative analysis between Slovenia and Bosnia-Herzegovina. Šumarski list, 135, 11-12: 557-566.

Pezdevšek Malovrh Š., Kumer P., Glavonjić P., Nonić D., Nedeljković J., Kisin B., Avdibegović M. 2017. Different organizational models of private forest owners as a possibility to increase wood mobilization in Slovenia and Serbia. Croatian Journal of Forest Engineering, 38, 1: $127-140$
Pezdevšek Malovrh Š., Laktić T. 2017. Poslovno povezovanje lastnikov gozdov na primeru društva lastnikov gozdov Pohorje - Kozjak. Zbornik gozdarstva in lesarstva, 113: 1-13.

Plevnik K. 2020. Analiza zadovoljstva članov Zveze lastnikov gozdov Slovenije z njenim delovanjem: magistrsko delo. (Univerza v Ljubljani, Biotehniška fakulteta, Oddelek za gozdarstvo in obnovljive gozdne vire). Ljubljana, samozal.: 75 str.

Põllumäe P., Lilleleht A., Korjus H. 2016. Institutional barriers in forest owners' cooperation: the case of Estonia. Forest Policy and Economics, 65: 9-16.

Poročilo Zavoda za gozdove Slovenije o gozdovih za leto 2018. 2019. Ljubljana, Zavod za gozdove Slovenije. http://www.zgs. si/fileadmin/zgs/main/img/PDF/LETNA_POROCILA/2018_ Porocilo_o_gozdovih.pdf (20. 2. 2020).

Resolucija o nacionalnem gozdnem programu (ReNGP). 2007. Ur. l. RS, št. 111/2007.

Ropret M. 2007. Značilnosti in usmerjanje razvoja gospodarjenja na drobni zasebni posesti na primeru GGE Cerklje: diplomsko delo. (Univerza v Ljubljani, Biotehniška fakulteta, Oddelek za gozdarstvo in obnovljive gozdne vire). Ljubljana, samozal: 55 str.

Sojč J. 2018. Presoja možnih oblik organiziranosti procesov proizvodnje in trženja lesa na območju KE Slovenske Konjice: magistrsko delo. (Univerza v Ljubljani, Biotehniška fakulteta, Oddelek za gozdarstvo in obnovljive gozdne vire). Ljubljana, samozal.: 84 str.

Statut Zveze lastnikov gozdov Slovenije. 2015. Zveza lastnikov gozdov Slovenije: 15 str.

Stoettner M.E., Ni Dhubhain A. 2019. The social networks of Irish private forest owners: an exploratory study. Forest Policy and Economics, 99: 68-76.

Šalka J., Dobšinska Z., Hricova Z. 2016. Factors of political power - the example of forest owners associations in Slovakia. Forest Policy and Economics, 68: 88-98.

Šinko M. 2012. Institucionalno in strukturno ozadje povezovanja gozdnih proizvajalcev. V : [na spletu]. 2012: 11-13. http:// web.bf.uni-lj.si/go/gsd2012/povzetki/2\%C5\%A0inko.pdf (28. 9. 2020).

Wästerlund D.S., Kronholm T. 2017. Family forest owners' commitment to service providers and the effect of association membership on loyalty. Small-scale Forestry, 16: 275-293.

Ustava Republike Slovenije. 1991. Ur. 1. RS, št. 33/91-I.

Weiss G., Gudurić I., Wolfslehner B. 2012. Review of forest owners' organizations in selected Eastern European countries. V: Forest policy an institutional working paper. Qiang M. (ur.) Food and Agriculture Organization of the United Nations, Rome: 57 str.

Winkler I., Medved M. 1994. Spremembe lastninske strukture gozdov zaradi denacionalizacije in njihove gozdnogospodarske posledice. Zbornik gozdarstva in lesarstva, 44: 215-246.

Zakon o društvih. 2006. Ur. 1. RS, št. 64/2006.

Zakon o gozdovih. 1993. Ur. 1. RS, št. 30/1993.

Zakon o spremembah in dopolnitvah Zakona o gozdovih. 2007. Ur. 1. RS, št. 110/2007. 